THE H UMAN ORGA NIZATION OF TIME 
- Recently, there has been an explosion in research on time. This book provides a much needed summary of that work. The Human Organization of Time will prove a valuable resource to anyone interested in temporal research in organizations.

LESLIE PERLOW, Harvard Business School.

- Finally a masterful book about time. Bluedorn's work is comprehensive and cutting edge, laying out the interplay of time with fundamental aspects of organizations and individuals. It should be on every serious organizational scholar's bookshelf.

KaThleen eisenhardt, Department of Management Science and Engineering, Stanford University

Coauthor of Competing on the Edge: Strategy as Structured Chaos

- This is a wonderful and important book, full of fascinating information, insights, conjectures, and constructs. Bluedorn forges a compelling case for the importance of time, and of our roles as current stewards of the temporal commons. From the Big Bang to the Bolshevik revolution to the puzzles of Deep Time, from the social construction of zero to the theory of relativity, from the gates of Trenton State Prison to the gates of Dante's Inferno, The Human Organization of Time weaves a compelling fabric of temporal threads. Bluedorn has found power and poetry in time.

RAMON ALDAG, Department of Management and Human Resources, University of Wisconsin

- The Human Organization of Time is a broad look at how we truly think about time. It unifies the many human patterns of time-scale concepts and gives depth and perspective to a complex field. Thorough and insightful, it will become the standard work.

GREgORY BENFORD, Department of Physics, University of California, Irvine

Author of Deep Time

- The Human Organization of Time stands to be a definitive source for those interested in temporality and time. Bluedorn's knowledge of diverse literatures and his attention both to historical perspectives as well as contemporary theorizing and research is noteworthy. Issues of time and temporality pervade the human experience; Bluedorn helps us to appreciate temporality as a social construction with very real consequences for organizations and their members.

JENNIFE M. George, Jesse H. Jones Graduate School of Management, Rice University

- A remarkable and original contribution to our understanding of the social construction of time and its effects on people and organizations. Playing off against a backdrop of work preoccupied with enduring and stable features of social life, Bluedorn underscores the importance of temporal features - pace, tempo, rhythm, entrainment, and historical turning points.

ALAN MEYER, Lundquist College of Business, University of Oregon 


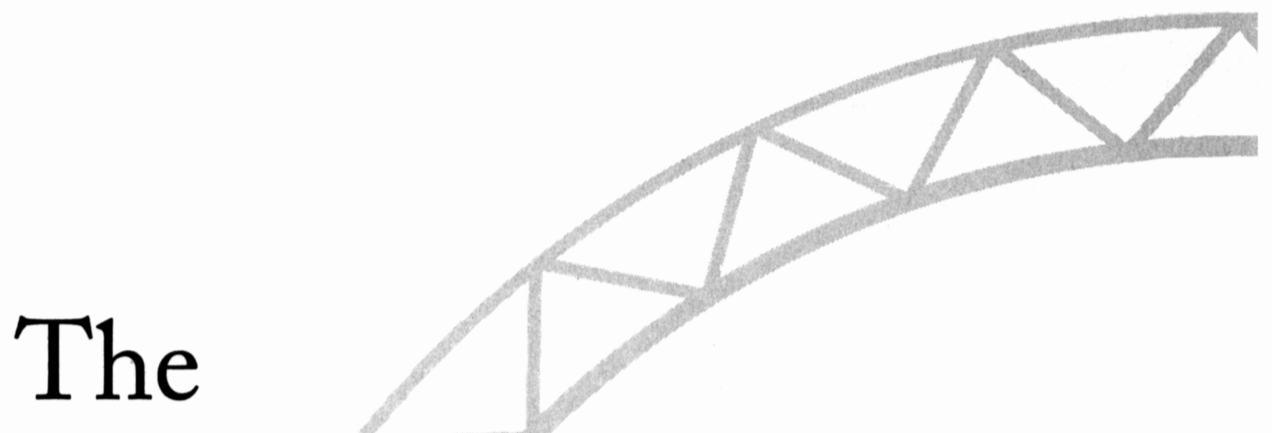

\section{Human Organization}

\section{of Time}

TEMPORAL REALITIES AND EXPERIENCE

Allen C. Bluedorn

STANFORD BUSINESS BOOKS

An Imprint of Stanford University Press 
Stanford University Press

Stanford, California

C 2002 by the Board of Trustees of the

Leland Stanford Junior University

Library of Congress Cataloging-in-Publication Data

Bluedorn, Allen C.

The human organization of time : temporal realities and experience / Allen C. Bluedorn.

p. cm. - (Stanford business books)

Includes bibliographical references and index.

ISBN 0-8047-4107-7 (alk. paper)

I. Time-Social aspects. 2. Time-Sociological aspects. I. Title. II. Series.

HM656 .B58 2002

304.2'3-de2I

2002001375

Original Printing 2002

Designed by James P. Brommer

Typeset in 10.5/14.5 Caslon 
To those who have brought such exquisite meaning to my times; may their times be the best of times always:

To my wife, Betty;

To my sons, John and Nick;

To my brother, Ralph;

To my mother, Evelyn;

To my father, Rudolph, 1905-1988. 
